\title{
ANALISIS PENGENDALIAN INTERN SIKLUS PERSEDIAAN DAN PENGGUDANGAN PADA PT. SAPTA SARI TAMA
}

\author{
Yudhi Powa ${ }^{1}$, Grace Nangoi ${ }^{2}$, Stanley Kho Walandouw ${ }^{3}$ \\ 1,2,3 Jurusan Akuntansi, Fakultas Ekonomi dan Bisnis, Universitas Sam Ratulangi, Jl. Kampus Bahu, Manado \\ 95115, Indonesia \\ Email : yudhipowa95@gmail.com
}

\begin{abstract}
PT. Sapta Sari Tama is a national company engaged in the distribution of medicines (pharmacy). Because there are quite a number of types of products and mobility in and out of goods so that the problems that are feared will occur, namely the physical difference between the inventory available in warehouse and the amount recorded in the inventory, loss or theft of goods stock, as a result, internal control of the inventory and warehousing cycles is needed so as not to occur fraud in carrying out the task. The purpose of this study was to determine whether the internal control of the inventory and warehousing cycles at PT. Sapta Sari Tama is sufficient. The method used in this study is a type of qualitative research presented in descriptive form. While data collection techniques are carried out by direct survey to PT. Sapta Sari Tama and interviewed several resource persons in the company. From the results of the study as a whole, internal control of the inventory and warehousing cycles is quite effective, where the company's management has implemented the concepts and principles of internal control. This is in accordance with the Regulation of Financial Accounting Standards (PSAK) No. 14 about inventory.
\end{abstract}

Keywords : Analysis, Internal Control, Inventory, Warehousing, PSAK No. 14

\section{PENDAHULUAN}

Perusahaan dagang ialah kegiatan usaha membeli barang dari perusahaan lain lalu menjualnya kembali kepada masyarakat. Salah satu unsur yang paling sering digunakan dalam perusahaan dagang ialah persediaan. Persediaan merupakan syarat pokok yang harus dipenuhi oleh suatu perusahaan dalam kegiatan perdagangan karena yang diperdagangkan ialah persediaan tersebut. Setiap aktivitas operasional perusahaan diutamakan pada usaha untuk melikuidasi persediaan tersebut sehingga menjadi kas beserta keuntungan yang diperoleh dari harga jual persediaan setelah dikurangi harga pokok penjualannya.

\section{TINJAUAN PUSTAKA}

Pengertian Akuntansi. Harahap (2013:2) menyatakan, "akuntansi ada juga yang sering menyebut accounting ialah bahasa bisnis yang dapat memberikan imformasi tentang kondisi bisnis dan hasil usahanya pada suatu waktu atau periode tertentu." Hadibroto (2013:207) "sistem akuntansi adalah metode dan penentuan yang ditetapkan untuk mengindikasi, mencatat, dan melaporkan transaksi-transaksi dalam organisasi untuk menjaga pertanggungjawaban neraca dan kewajiban.

Akuntansi Keuangan. Giri (2014:6) “akuntansi keuangan (financial accounting) adalah proses yang berkulminasi pada penyiapan dan pengkomunikasian laporan keuangan suatu entitas untuk digunakan oleh pihak internal dan eksternal.” Menurut Kieso (2016:6) "akuntansi keuangan adalah proses mengolah laporan keuangan suatu perusahaan yang nantinya akan digunakan oleh pengguna laporan keuangan antara lain investor, kreditor, dan pihak internal lainnya. 
Laporan Keuangan. Kasmir, (2013: 7) menyatakan "laporan keuangan adalah laporan yang menunjukkan kondisi keuangan perusahaan pada saat ini atau dalam suatu periode tertentu." Munawir (2013:5) "laporan keuangan adalah dua daftar yang disusun oleh Akuntan pada akhir periode untuk suatu perusahaan.

Pengertian Pengendalian Intern. Krismiaji (2015:220) "Committee of Sponsoring Organization (COSO) mendifinisikan pengendalian intern sebagai sebuah proses yang melekat dalam kegiatan oprasional sebuah organisasi dan merupakan bagian yang integral dari aktivitas dasar manajemen seperti perencanaan, pelaksanaan dan pemantauan kegiatan organisasi." Hery (2015:159) menyatakan, "Pengendalian intern adalah seperangkat kebijakan dan prosedur untuk melindungi asset atau kekayaan perusahaan dari segala bentuk tindakan penyalahgunaan, menjamin tersedianya informasi akuntansi perusahaan yang akurat, serta memastikan bahwa semua ketentuan (peraturan) hukum/undang-undang serta kebijakan manajemen telah dipatuhi atau dijalankan sebagaimana mestinya oleh seluruh karyawan perusahaan.

Tujuan Pengendalian Intern. Tunggal (2013:4) mengemukakan "bahwa sesuai dengan Standards for The Professional Practice of Internal Auditing (Standard 300), Scope of Work, 5 tujuan utama pengendalian intern adalah untuk meyakinkan: (1) Keandalan dan integritas informasi, (2) Ketaatan dengan kebijakan, rencana, prosedur, hukum dan peraturan, (3) Mengamankan aktiva, (4) Pemakaian sumber daya yang ekonomis dan efisien, (5) Pencapaian tujuan dan sasaran operasi atau program yang ditetapkan.

Unsur-unsur Pengendalian Intern. Krismiaji (2015:222) menyatakan "unsur-unsur pengendalian intern sebagai berikut: (1) Lingkungan pengendalian (Control Environment), (2) Aktivitas Pengendalian (Control Activities), (3) Informasi dan komunikasi, (4) Pengukuran Resiko, (5) Pemantauan.

Pengendalian Intern Siklus Persediaan dan Penggudangan. Arens, Elder, Beasley (2014:306) mengemukakan "siklus persediaan dan pergudangan adalah siklus yang unik karena erat hubungannya dengan siklus transaksi lainnya. Bahan baku dan buruh langsung masuk dalam siklus persediaan dan pergudangan, masing - masing dari siklus pembayaran dan perolehan. Siklus persediaan dan pergudangan diakhiri dengan penjualan barang dalam siklus penjualan dan penerimaan kas.

Persediaan. Menurut Syakur (2015:140) "persediaan meliputi segala macam barang yang menjadi objek pokok aktivitas perusahaan yang tersedia untuk diolah dalam proses produksi atau dijual. Pada perusahaan dagang tentu saja barang-barang yang menjadi objek pokoknya adalah barang-barang yang akan (dibeli) untuk dijual kembali. Barang-barang demikian ini disebut persediaan barang dagangan (merchandise inventory)." Midjan La dan susanto (2013: 155) mengungkapkan bahwa, "pengendalian persediaan adalah semua metode dan tindakan yang digunakan untuk mengamankan persediaan sejak dari kedatangan, menerima, meyimpan dan mengeluarkannya, baik fisik maupun kualitas dan pencapaiannya terutama penentuan dan pengaturan jumlah perusahaan"

Penelitian Terdahulu. Ade Irmayani (2013). “Analisis Persediaan Barang Dagang pada CV. Kawal Pantai Bintan. Penelitian ini menyatakan bahwa akuntansi persediaan pada CV. Kawal Pantai Bintan belum sesuai dengan PSAK Nomor14 (Revisi 2008), seperti tidak adanya biaya persediaan, biaya lain-lain dan biaya konverrsi pada pengukuran persediaan biaya standar pada Teknik pengukuan biayanya, tidak ada pemulihan kembali pada pengakuan sebagai bebandan tidak adanya penurunan nilai. Aprilia Makisurat (2014) "Penerapan Sistem Pengendalian Intern untuk Persediaan Barang Dagangan pada CV. Multimedia Persada Manado. CV. Multi Media Persada Manado atas pengendalian intern sudah baik, karena telah menerapkan unsur-unsur pengendalian intern. Disarankan pihak manajemen dapat melakukan pencatatan manual serta menyediakan staf ahli dalam menilai kualitas barang dagangan. 


\section{METODE PENELITIAN}

Jenis Penelitian. Penelitian ini termasuk jenis deskriptif kualitatif, dimana penulis secara langsung mendatangi objek penelitian yaitu untuk memperoleh data-data dan informasi yang dibutuhkan dalam menganalisis efektivitas pengendalian intern persediaan barang dagangan.

Tempat dan Waktu Penelitian. Penelitian ini dilakukan pada PT. Sapta Sari Tama yang beralamat di Sario Kotabaru, Sario, Kota Manado, Sulawesi Utara, Indonesia. Adapun penelitian dilaksanakan selama 3 bulan.

Jenis, Sumber dan Metode Pengumpulan Data. Dalam penelitian ini, jenis data yang digunakan adalah data kualitatif, dimana data tersebut berupa gambaran umum PT. Sapta Sari Tama, dan struktur organisasi. Sumber data yang digunakan dalam penelitian ini melalui Data Primer. Metode pengumpulan data yang digunakan: (1) Survei Pendahuluan (2) Survey lapangan (a) Teknik Dokumentasi; (b) Teknik Wawancara;

Metode Analisis Data. Didalam menganalisa pengendalian intern siklus persediaan dan penggudanggan, penulis melakukan perbandingan antara teori Committee of Sponsoring Organization (COSO) dengan teori yang diterapkan pada perusahaan. Adapun pertanyaanpertanyaan yang dipakai penulis adalah sebagai berikut: (1) bagaimana gambaran umum pada pt. sapta sari tama ?, (2) bagaimana penerapan unsur-unsur pengendalian intern persediaan barang pada pt. sapta sari tama ? (a) lingkungan pengendalian, (b) aktivitas pengendalian, (c) informasi dan komunikasi, (d) pengukuran resiko, (e) pemantauan.

\section{HASIL ANALISIS DAN PEMBAHASAN}

\subsection{Hasil Analisis}

Lingkungan Pengendalian (Control Environment). Lingkungan pengendalian PT. Sapta Sari Tama terdiri dari tindakan, kebijakan dan prosedur yang menggambarkan sikap seluruh perusahaan. Lingkungan pengendalian di PT. Sapta Sari Tama dapat dijelaskan sebagai berikut: Integritas dan nilai etika yang dilaksanakan pada PT. Sapta Sari Tama ditetapkan oleh business manager perusahaan dengan menetapkan peraturan-peraturan tata cara karyawan tentang etika dan perilaku yang diinformasikan kepada setiap karyawan dan harus dilakukan oleh setiap karyawan. Jika ada karyawan yang tidak melakukan aturan yang ditetapkan, maka dari business manager akan menegur karyawan tersebut secara baik-baik. Aturan mengenai tata cara karyawan ditetapkan agar dapat mendorong karyawan bertindak jujur, sopan, sesuai dengan etika dan peraturan yang ditetapkan business manager PT. Sapta Sari Tama.

Aktivitas Pengendalian (Control Activities). Aktivitas pengendalian di PT. Sapta Sari Tama berupa kebijakan dan prosedur yang dijalankan dalam perusahaan yang bisa menjamin sistem yang telah dianut dapat berjalan efektif. Aktivitas PT. Sapta Sari Tama dapat dijelaskan sebagai berikut :Otorisasi yang tepat terhadap transaksi dan aktivitas. Penentuan fungsi yang diotorisasi yang telah ditetapkan di PT. Sapta Sari Tama. Otorisasi atas transaksi di PT. Sapta Sari Tama adalah sebagai berikut: Pada aktivitas permintaan barang untuk toko diotorisasi oleh business manager.

Informasi dan Komunikasi. Sistem informasi yang diterapkan oleh PT. Sapta Sari Tama sudah cukup baik. Dalam pelaksanaan transaksi terdiri dari pemesanan, penerimaan, perhitungan dan pengeluaran persediaan barang dagangan, berjalan sesuai dengan penyusunan prosedur, serta pengawasan terhadap persediaan barang dagangan yang menggunakan beberapa dokumen dan catatan berupa database dari pihak gudang selaku penyetok barang dagangan dalam gudang maupun faktur-faktur pembelian barang dagangan dari konsumen dan toko - toko dalam order barang.

Pengukuran Resiko. PT. Sapta Sari Tama menilai persediaan alat kesehatan dan obat-obatan dengan melihat masa pakainya karena persediaan obat-obatan merupakan barang 
yang harus digunakan sebelum habis masa pakainya. Sehingga apabila tiba masa kadaluarsanya produk farmasi tersebut akan mengakibatkan resiko berkurangnya penjualan dan menyebabkan kerugian.

Pemantauan. Pemantauan yang dilakukan PT. Sapta Sari Tama sehubungan dengan kegiatan transaksi penerimaan dan pengeluaran barang dagangan ialah dengan memantau dan memeriksa secara rutin aktivitas kerja dari setiap fungsi-fungsi yang terkait, apakah sudah sesuai dengan metode dan prosedur. Pemantauan atas persediaan barang dagangan secara khusus meliputi penilaian dan penganalisian laporan stock opname setiap bulan untuk disesuaikan dengan perkembangan permintaan konsumen.

Jenis-Jenis Persediaan. Persediaan yang ada di PT. Sapta Sari tama adalah persediaan barang dagang yang dibeli dan dijual kembali. Jenis - jenis persediaan barang dagang yang ada di PT. Sapta Sari Tama dapat dilihat dari: (1) Persediaan baik digudang yaitu persediaan yang disimpan sementara digudang penyimpanan sebelum dijual. (2) Persediaan rusak yaitu persediaan yang kualitasnya tidak sama seperti semula atau sudah habis masa kadaluarsanya yang dapat dijual atau dicadangkan dalam persediaan rusak.

\subsection{Pembahasan}

\section{Analisis Unsur-unsur Pengendalian Intern Persediaan Barang}

Lingkungan Pengendalian (Control Environment). Business manager PT. Sapta

Sari Tama menyatakan lingkungan pengendalian atas persediaan barang dangangan. Lingkungan pengendalian persediaan barang dagangan pada PT. Sapta Sari Tama dianalisis berdasarkan faktor-faktor yang menyusun lingkungan pengendalian dari perusahaan. Komitmen Kepada Integritasi dan Nilai Etika. Integritasi dan niali-nilai etika dalam PT. Sapta Sari Tama sudah memadai, dimana karyawan dituntut untuk lebih bekerja dengan disiplin, jujur dan bertanggung jawab. Dan akan ada sanksi jika melakukan pelanggaran etika. Hal ini bertujuan untuk membentuk komitmen dan etika terhadap rasa tanggung jawab serta integritasi perusahaan.

Aktivitas Pengendalian (Control Activities). Aktivitas transaksi berupa pembukuan tanda tangan oleh orang yang berwenang pada dokumen untuk transaksi tersebut.

Informasi dan Komunikasi. Kegiatan sistem informasi dan komunikasi yang dilakukan PT. Sapta Sari Tama sudah cukup baik. Hal ini dapat dilihat dari penyusunan prosedur yang jelas didalam perusahaan, termasuk dalam prosedur pengawasan persediaan barang dagangan yang melibatkan beberapa fungsi terkait, dokumen dan catatan yang diperlukan serta laporan yang dihasilkan dan pencatatan kedalam catatan akuntansi harus didasarkan atas laporan sumber yang dilampiri dengan dokumen pendukung yang lengkap dan diotorisasi oleh pihak yang berwenang.

Pengukuran Resiko. Pengukuran resiko yang dilakukan oleh business manager agar penyanjian informasi persediaan barang dagangan adalah wajar dan tepat waktu sudah cukup baik. Business manager telah mengenali dan mempelajari resiko-resiko yang ada, serta membentuk aktivitas-aktivitas pengendalian yang diperlukan untuk menghadapi hal tersebut.

Pemantauan. Pemantauan dilakukan dengan membantu business manager untuk mencari tahu ketidakefektifnya pelaksanaan unsur-unsur pengendalian yang lain. PT. Sapta Sari Tama melakukan pemantauan persediaan barang dagangan dengan cara stock opname setiap bahannya untuk disesuaikan dengan perkembangan permintaan konsumen, serta memperhatikan pengeluhan pelanggan. Evaluasi agar penyimpangan yang ditemukan juga merupakan tanggapan yang baik dan mencerminkan adanya kesadaran akan pentingnya pengendalian yang tertanam dalam diri manajemen. 


\section{KESIMPULAN DAN SARAN}

\subsection{Kesimpulan}

Berdasarkan penelitian yang dilakukan oleh peneliti pada PT. Sapta Sari Tama mengenai Analisis Pengendalian Intern Siklus Persediaan Dan Penggudangan dapat ditarik kesimpulan sebagai berikut: Secara keseluruhan pengendalian intern persediaan barang dagang berjalan efektif, hal ini ditunjukkan dengan telah diterapkannya unsur-unsur pengendalian intern. Namun, dari ke lima unsur pengendalian intern yang telah dijabarkan pada hasil penelitian dan pembahasan, menunjukan bahwa masih ada beberapa yang kurang, dalam lingkungan pengendalian khususnya pada struktur organisasi tidak memiliki bagian akuntansi, dimana bagian ini adalah bagian yang penting dalam suatu perusahaan.

\subsection{Saran}

Berdasarkan kesimpulan diatas, penulis memberikan saran kepada PT. Sapta Sari Tama sebagai berikut:

1. Untuk menciptakan pengendalian intern yang lebih memadai terhadap persediaan perusahaan sebaiknya membentuk bagian auditor internal sehingga dapat menyelidiki dan menilai efektivitas pelaksanaan unsur-unsur pengendalian intern persediaan barang yang ditetapkan business manager.

2. Pemisahan tugas operasi, pencatatan, dan penyimpanan kas sebaiknya dilakukan dengan memadai, dimana kasir sebagai penyimpanan kas perusahaan dan tidak boleh memiliki akses ke sistem komputer untuk melakukan pencatatan terhadap penjualan barang dagangan.

\section{DAFTAR PUSTAKA}

Arens, Elder, Beasley.2014. Auditing dan Pelayanan Verifikasi, edisi 9, Jakarta: PT. Indeks. Ade, 2013. Analisis Persediaan Barang Dagang pada CV. Kawal Pantai Bintan. Universitas Gadjah Mada Fakultas Ekonomi. Diakses Febuari 2018.

Aprilia, 2014. Penerapan Sistem Pengendalian Intern untuk Persediaan Barang Dangangan pada CV. Multimedia Persada Manado. Universitas Samratulangi Manado Fakultas Ekonomi dan Bisnis. Jurnal Emba Vol. 2 No. 2, Hal. 1151-1161. Diakses Febuari 2018.

Giri, 2014. Akuntansi Keuangan Menengah 1. Yogyakarta. UPP STIM YKPN.

Hadibroto, 2013. Sistem Akuntansi. Ghalia Indonesia, Jakarta.

Harahap, Sofyan Safitri. 2013. Analisis Kritis atas Laporan Keuangan. Jakarta; Raja Grafindo Persada.

Hery, 2015, Akuntansi Intermedite Illustrasi Problem dan Solusi, Edisi 1, Grasindo, Jakarta. Kasmir. 2013. Analisis Laporan Keuangan . Jakarta: PT. Raja Grafindo Persada.

Kieso, Jerry J, Terry Warfield. 2016. Financial Accounting IFRS Edition. Penerbit: WILEY, Hoboken New Jersey

Krismiaji. 2015. Sistem Informasi Akuntansi. Jogjakarta: UUP STIM YKPN.

Midjan La dan Susanto, 2013. Sistem Informasi Akuntansi. Edisi Kedelapan. Linggajaya, Bandung.

Munawir. 2013. Analisa Laporan Keuangan. Yogyakarta : Liberty.

Syakur, 2015. Intermediate Accounting. Edisi Revisi. Penerbit Pembuka Cakrawala, Jakarta. Tunggal, Amin. 2013. Pokok - pokok COSO Based Auditing. Penerbit: Harvarindo, Jakarta. 